This is an electronic reprint of the original article. This reprint may differ from the original in pagination and typographic detail.

Author(s): Ihalainen, Pasi; Matikainen, Satu

Title: $\quad$ The British Parliament and Foreign Policy in the 20th Century : Towards Increasing Parliamentarisation?

Year: $\quad 2016$

Version:

Please cite the original version:

Ihalainen, P., \& Matikainen, S. (2016). The British Parliament and Foreign Policy in the 20th Century : Towards Increasing Parliamentarisation?. Parliamentary History, 35(1), 1-14. https://doi.org/10.1111/1750-0206.12180

All material supplied via JYX is protected by copyright and other intellectual property rights, and duplication or sale of all or part of any of the repository collections is not permitted, except that material may be duplicated by you for your research use or educational purposes in electronic or print form. You must obtain permission for any other use. Electronic or print copies may not be offered, whether for sale or otherwise to anyone who is not an authorised user. 


\title{
The British Parliament and Foreign Policy in the 20th Century: Towards Increasing Parliamentarisation?
}

\author{
Pasi Ihalainen and Satu Matikainen \\ University of Jyvaskyla
}

\begin{abstract}
This article demonstrates the complexity of the foreign policy involvement of the British parliament during the twentieth century. Parliamentary government as such provides some procedural means for involvement in foreign policy debate, in Britain as well as in other countries. Researchers have nevertheless often argued that parliaments play a limited role in foreign policy. Approaching our topic by combining the analysis of policy documents with more discourse-oriented analysis of parliamentary debates, we argue that noticeable but not straightforward parliamentarisation of foreign policy took place in the course of the twentieth century. The aftermath of the First World War led to reconsiderations of the degree of parliamentary supervision of foreign policy. The emergence of international organisations, and, recently, European integration have also complicated parliamentary participation in foreign affairs. The parliamentary oversight of foreign policy is no longer limited to the national level, which has, in the British case, led to calls to reinforce the sovereignty of the national parliament. On the domestic level, parliamentary debates need to be contextualised with extra-parliamentary public discourse. The relation of parliament to civil society at large,
\end{abstract}


especially nongovernmental organisations and the media, has created multi-sited debates, further strengthening democratic control of foreign policy.

Key words: parliamentary history, British parliament, foreign policy, constitution, parliamentarisation, international organisations, European integration, media, civil society

Historically, the role of national parliaments in the running or even scrutinising of foreign policy has been seen as very limited. Foreign relations have traditionally been regarded as belonging to the monarchical prerogative, and hence full responsibility for foreign policy has usually been located in the executive. The historical precedents offered by 'ruling' parliaments, such as those in 18th-century Sweden or Poland, have not been particularly encouraging. In the case of the Westminster system, the foreign policy role of parliament has often been overlooked, especially when it comes to the 20th century. There have also been practical and procedural reasons for the exclusion of foreign policy issues from direct parliamentary control. Parliaments have focused on legislation, and allowing a sufficient amount of deliberation for dealing with legislative processes would be difficult if parliamentarians or committees became constantly involved in executive and administrative tasks. Foreign affairs and intergovernmental agreements rarely require legislation, and this automatically decreases the time spent on debates concerning international relations. ${ }^{1}$ However, parliamentary activities consist of much more than the mere passage of laws and the scrutiny of government. Parliamentary government has traditionally been associated with the power to decide on the annual budget of nation states, whereas demands for the parliamentary supervision of foreign policy only started to emerge during the First World War, and the role of parliaments as forums for the public discussion of this field, too, was strengthened as a result of these demands. 
However, even in the recent past, foreign affairs have been considered to be too sensitive or difficult to be subjected to parliamentary debate. Foreign policy calls for expertise and seems to be a field that is best left to highly trained experts - the elite civil servants who represent the foreign ministries - and these have not welcomed the involvement of ordinary, less educated and less well-informed members of parliament in detailed foreign policy discussions - let alone in making decisions about diplomatic matters. Thus foreign policy has rather been seen as a field to be determined by heads of state, leading ministers and foreign ministries, whose decisions need only afterwards be scrutinised by representative institutions. Nor have the representative institutions themselves usually been very interested in the details of relations with foreign powers - except in cases of public controversy or the personal voluntary or institutional involvement of individual MPs in particular questions.

In this special issue, we argue that the possibilities for members of parliament to participate in foreign policy debates has tended to increase gradually in Britain and several other countries since the First World War. Governments have, often in response to interaction with MPs and as part of a wider process of democratisation, started to inform parliaments about their foreign policy activities, and the role of the parliaments has consequently strengthened. Opportunities for parliament to discuss foreign policy issues have existed in Britain since the 18th century, and parliamentary questions were used occasionally in the long 19th-century and, as we shall show, were effectively employed in the interwar and postSecond-World-War periods. The increasing distribution of information, which was also initiated by governments themselves, can be seen as a measure aimed at strengthening the legitimacy of decision-making by allowing parliaments to discuss foreign policy issues as part of a broader public debate, something that has been generally recognised as essential for a functioning parliamentary democracy. Parliament provides a forum through which the government can communicate with a wider public and create support for its policies - rather than one where those policies would actually be formulated. This regulated 
parliamentarisation of foreign policy in Western parliamentary democracies is linked to the diversification of the media in the course of the 20th century: the printed and electronic media are able to provide increasingly up-to-date information on events and diverse views on foreign policy issues, so governments consider it necessary to provide parliaments and the general public with corresponding updated information and to allow public and related parliamentary debates to at least seemingly contribute to the solution of foreign policy questions.

Parliaments can rarely 'solve' foreign policy conflicts, but they do provide a forum in which adopted policies can be scrutinised and alternatives presented. They also provide a forum for seeking compromise and consensus, which have traditionally been highly esteemed values, especially in the field of national foreign policy. Parliaments have been, at least in the domestic politics of most countries in most periods, successful institutions for the control of governments by the representatives of the people and the solving of internal conflicts by peaceful means, relying on pro et contra debate rather than the use of coercion. The suitability of parliaments for solving international conflicts is, however, far from clear given their essentially national(ist) character. On the other hand, attempts to solve international conflicts call for the legitimation of the use of power by the national executive or intergovernmental organisations, and in parliamentary democracies such legitimation primarily takes place through representation and parliamentary debate.

As a consequence, foreign policy debates have become more open and more challenging for foreign-policy-makers than has traditionally been the case. The studies in this issue suggest that national foreign policies have tended to gradually become more parliamentarised. This could be seen concretely when the British parliament overrode the government in August 2013 over the use of force in the Syrian Civil War. This parliamentarisation process has not been a linear one, however, and historians need to analyse whether, how and why such a gradual process has taken place and what the potential implications and remaining limitations on such a parliamentarisation of foreign policy are. 
However, we make no normative assumptions implying the positive effects of the involvement of parliaments in foreign policy; parliamentary democracies are just as capable of engaging in wars as are totalitarian regimes. Rather, we aim at a deeper understanding of the reasons, realities, conceptions and consequences of the suggested development, taking into account counter-arguments to the existence and potentially positive implications of the parliamentarisation of foreign policy.

This parliamentary involvement in national foreign policy has simultaneously become more complicated as a consequence of the cumulative construction of a supranational level of foreign policy decision-making. International organisations have affected the work of national parliaments at least since the founding of the League of Nations in the aftermath of the First World War. The international level has opened up possibilities for the members of national parliaments to discuss the national policy to be followed in these organisations as well as the policy lines that the organisations at large should adopt. A central question for both parliamentary government at the level of nation states and the prospects for international organisations such as the European Union is whether foreign policy can be parliamentarised at a supra- and transnational level in addition to the national one. The gradually strengthening role of the European Parliament as a foreign-policy-making body has further changed the ways in which the relationship between parliaments and foreign policy is understood. The implications of international organisations for parliaments and foreign policy are also addressed in this issue, with reference to both the interwar era and contemporary history.

\section{New Approaches to Parliamentary History}

The contextualised case studies of this volume demonstrate the complexity of the foreign policy involvement of the British parliament in the 20th century. The general opinion among researchers has been that parliaments play a minor and limited role in foreign affairs. 
Parliamentary aspects have often been bypassed in research on political history, and the responsibilities of the executive branch have been highlighted. As Peter G. Richards argued in his 1967 study Parliament and Foreign Affairs, 'the record of Parliament in foreign affairs is unimpressive' owing to its lack of both interest and knowledge. ${ }^{2}$ Later studies on the subject have generally agreed over the very limited role of parliament in British foreign policy. Traditionally, foreign affairs were a royal prerogative issue that was reserved for the sovereign, and by extension the cabinet. The role of parliament in foreign relations has thus far mostly been treated either by social scientists or in the context of specific historical situations. An example is a volume edited by Carstairs and Ware, Parliament and International Relations (1991), which discusses how the British parliament works in foreign affairs. The limited foreign policy role of parliaments in the Anglophone countries, despite attempts to address human rights and the democratic deficit and to cooperate with voluntary associations and international organisations, has been emphasised by other scholars as well. ${ }^{3}$

Recent research in social science and law has recognised the changing role of national parliaments in foreign policy as a consequence of globalisation and European integration. ${ }^{4}$ The political scientists Ben Crum and John Erik Fossum ${ }^{5}$ suggest that transnationalism tends to increase as parliamentarians coordinate their work across boundaries. The current situation, in which parliamentarians involve themselves both in foreign policy issues at the nation-state level and in outright transnational questions prompts us to reconstruct and analyse long-term tendencies in the parliamentarisation of foreign policy during the 20th century at the national level, in this case in Britain.

Research on the history of international relations - and indeed political history in general - with a special and explicit focus on parliaments has remained rather scarce. Parliamentary records have often served as a supplement to other types of primary sources, such as the archives of various governmental departments or the personal papers of 
politicians. The traditional study of political history with regard to foreign policy has focused on the analysis of diplomatic documents available in national archives. In a recent article, Phoebe Chow has remarked that historians have concentrated on the actions of top-level officials and the cabinet, but she sees this focus on high-level diplomacy as largely necessary. ${ }^{6}$

Historians of political cultures, political scientists and linguists focusing on parliamentary discourse have recently mainly used parliamentary debates as source material in their work. ${ }^{7}$ Our approach to the study of foreign policy combines the two: while building on the analysis of policy documents, it also considers parliamentary debates and is more discourse-oriented than traditional diplomatic history. We have, therefore, approached the role of parliament in foreign policy by utilising a wide variety of primary sources. Hansard constitutes the central starting point for the analysis, but it is supplemented by other parliamentary papers such as committee reports. In order to form as complete a picture as possible, it is also essential to utilise sources created by other political actors. These include the foreign office, other relevant government departments, the media, intergovernmental organisations and voluntary associations. For example, the records of the foreign office provide a necessary background not only to the opinions and actions of the government but also to the immediate reactions to parliamentary pressure. Parliamentary debates are, therefore, analysed side by side with archival documents, public debates and interviews in order to grasp the multi-sited nature of policy discourse, a discourse that exists in interconnected debates about the possibilities and shortcomings of parliamentarised foreign policy taking place in a variety of forums at the same time.

A further methodological incentive for this issue has been the availability of electronic databases on parliamentary records: full-text searches have been initially used to locate sources for contextual analyses of parliamentary debates. The sheer extent of parliamentary 
records has previously complicated their use in historical research. While digitisation opens up possibilities for a computerised analysis of parliamentary discourse, our ambition has been rather more modest: simply to exploit the possibility of locating potentially interesting debates and to analyse them comparatively using the historical methods of close reading and contextualisation within a multi-sited policy discourse - multi-sited in the sense that sources created outside parliament have also been exploited.

In this introductory essay to the accompanying five case studies, we draw on both the empirical data analysed in them and on previous research and articles to put forward a number of theses about the nature of parliamentary involvement in foreign policy and related constitutional questions: (i) the aftermath of the First World War led to reconsiderations of the degree of parliamentary oversight of foreign policy; (ii) in the course of the 20th century, the gradual parliamentarisation of foreign policy is visible but far from straightforward; (iii) parliamentary government as such provides some procedural means for involvement in foreign policy debate; (iv) the ability of parliamentarians to act in several national forums simultaneously has created possibilities for broader participation in the discussion of foreign policy; and (v) since the early 20th century the environment of parliament has gradually become more international (and potentially transnational), and this has tended to strengthen the constitutional role of parliaments in national foreign policy as well.

\section{The Evolving Constitutional Roles of Parliaments in Foreign Policy in the Early 20th}

Century

Since the late 18th century at least, parliamentary debates have had the potential to open up some foreign policy phenomena to public discussion and in that sense to 'democratise' foreign policy. Foreign policy was occasionally debated in the British parliament in 
connection with the French Revolutionary Wars and also in other representative institutions of 'free' states such as the Swedish Diet in the 1760s and the Dutch National Assembly in the 1790s. ${ }^{8}$ A.J.P. Taylor and Peter Richards have both drawn attention to the relatively strong parliamentary influence on foreign policy in the mid 19th century, for example during the Crimean War. ${ }^{9}$ The late 19 th century, however, marked a fading parliamentary interest in foreign affairs and also fewer possibilities for MPs to intervene in government policy. This was caused, among other things, by procedural changes in the Commons and increased party discipline. $^{10}$

A British peculiarity that increases the potential for the parliamentarisation of foreign policy is the lack of a written constitution. The openness of the British constitution for addressing contingent disputes and the unfixed nature of the parliamentary system (despite its established traditions) have often facilitated evolution as they make the constitution adaptable to the demands of a wide variety of particular circumstances. Unlike countries with written constitutions, there is no formal procedure for changing the constitution in the British system; changes can be made by a parliamentary majority in the same way as any changes in legislation. ${ }^{11}$ As a consequence, the British constitution has been renewed considerably by parliament since early modern times. The most significant turning points have included the 17th-century regularisation of parliamentary sessions and the introduction of budgetary power; the 18th-century institution of the supremacy of parliament vis-à-vis the monarchy, the establishment of a parliamentary opposition and the development of votes of no confidence; the 19th-century extension of representation, the parliamentarisation of government and the rise of parliamentary publicity; the early 20th-century recognition of the Commons as the location of parliamentary sovereignty and the democratisation of suffrage; and in the late 20th century the creation of the committee system and adaptation to European integration. ${ }^{12}$ The articles in this issue suggest that the parliamentarisation of foreign policy has recently intensified. 
The evolutionary nature of the British parliamentary system allows the parliamentarians a space for manoeuvre which, if successfully and repeatedly exploited, can potentially lead to redefinitions of the constitutional role of the House in the field of foreign policy. Such attempts can already be found in the time preceding the First World War. During the first years of the 20th century, concerns among MPs over the secrecy of great power diplomacy and treaties increased considerably. ${ }^{13}$ Anssi Halmesvirta's recent article, for example, charts out the rise of extra-parliamentary networks in attempts to influence colonial policies in the early 20 th century. ${ }^{14}$

Throughout the First World War, the British and French parliaments relatively successfully opposed attempts to shift executive power to non-parliamentary agencies and thereby preserved parliamentary legitimacy. ${ }^{15}$ The last phase and the immediate aftermath of the war entailed attempts on both the combatant sides and also in neutral countries to change the role of parliaments in foreign policy decision making. Domestic parliamentary government by negotiation was sometimes presented as a model for a new kind of foreign policy that would be based on discussions with other parties and would give sufficient consideration to public opinion at home and abroad. ${ }^{16}$ In reality, however, proposals to parliamentarise the activities of the foreign ministry and diplomacy did not find much support in the interwar period anywhere. Nevertheless, the momentum of 1917-19 for the democratisation and parliamentarisation of all aspects of government at the level of nation states and visions about the role of the League of Nations created theoretical possibilities for the reorganisation of both national foreign policy and the international system.

In Britain, the Union of Democratic Control (UDC) agreed with arguments presented on the continent that secret diplomacy had been largely responsible for triggering the First World War and that public opinion might curb such excesses if only it knew what was happening. The organisation was created in 1914 among the ranks of radical Liberals, but after the First World War the majority of former UDC Liberals joined the Labour Party. ${ }^{17}$ By the interwar 
period, the confidence of individual MPs as actors in foreign policy had increased further. In 1924, after a long campaign, the Union of Democratic Control won a concession from the Labour government called the 'Ponsonby Rule', which stipulated that treaties must be laid before the house of commons twenty-one parliamentary days before they took effect. This seemingly small matter is often mentioned as an important milestone on the road towards the parliamentarisation of foreign policy. ${ }^{18}$

Archival sources generated by the relevant departments may reveal interaction between the executive branch and parliament or parliamentarians. Satu Matikainen shows in her contribution how both MPs and peers skilfully utilised a number of available procedural strategies to circumvent the limited constitutional role of parliament in foreign affairs and even to extend it. Coordinated parliamentary questions together with private letters and public statements on the League of Nations minority protection system provided a means of exerting parliamentary pressure in the running of foreign affairs. These strategies were used to maintain and even strengthen the parliamentary scrutiny of foreign policy - and they were quite successful to judge by the seriousness with which the questions were answered by the executive. In many cases, the government and the civil servants clearly attempted to control the information that was made available to parliament, and the efforts of the MPs were seen as 'meddling'. However, the foreign office was forced to recognise, at least to some extent, the democratic controlling role of parliament.

Moving on towards the Second World War, many historians have mentioned the 'Norway Debate' as an example of an important instance of parliamentary control of foreign policy. The Commons debate was initiated by Neville Chamberlain's government on 7 and 8 May $1940 .{ }^{19}$ In the debate, widespread dissatisfaction with the government's foreign policy manifested itself in both government and opposition ranks. The opposition finally forced a vote, which the government won with a reduced majority. The government was soon brought 
down, albeit not as a direct result of the Commons vote, as some historians have claimed, but rather because the government had clearly lost its credibility. ${ }^{20}$

\section{Parliamentary Involvement in Foreign Policy since the Second World War}

Further changes in the status of parliament within the British constitution with regard to foreign policy would seem to have taken place after the Second World War, though scholars are strongly divided over this development. Carstairs and Ware, for instance, have pointed out that the emergence of nuclear weapons and the Cold War period may actually have reinforced the idea of limited parliamentary access to foreign policy. ${ }^{21}$ However, Matti Roitto's analysis of the immediate post-war situation shows how, despite continuing constitutional limitations to parliamentary power, the MPs succeeded in defining the atomic question as a matter of foreign policy which they wanted to discuss and influence. Parliament was able to 'seize the moment' in a highly important issue, which gradually gave it access to foreign affairs. ${ }^{22}$

Even if the government remained constitutionally dominant in foreign affairs, parliamentarians were able to challenge that status by making use of the dynamic relationship between parliament and the executive, demanding information from the government and seeking further information from the media and through personal contacts. Roitto shows how this constitutional control was exerted by both opposition and government MPs using oral questions and adjournment debates. This happened in spite of the fact that there is evidence that information was deliberately withheld from parliament. During the briefing for the adjournment debate of 30 October 1945 on atomic energy, the cabinet office prepared a memorandum in which there was a section titled 'Notes on points to be avoided', i.e. in the

Commons debate. ${ }^{23}$ Roitto also shows how the deliberate exploitation of parliamentary pressure in bilateral negotiations to persuade a foreign power to make concessions took place 
- a diplomatic practice that as a consequence of globalisation and integration has become increasingly important in relations between representative democracies.

Parliament had traditionally used committees made up of members of parliament to undertake specific investigations, and such committees began to be utilised more often in the 20th century. Particularly from the 1960 s onwards, there were calls for a more permanent system of parliamentary committees. Select committees, including the foreign affairs committee, were finally introduced in 1979, later than in most Western representative democracies, thus marking a turning point in the handling of foreign policy issues in parliament.

The creation of the committee system was related to the accountability of the executive to parliament. In a way, one can say that the parliamentarisation of foreign policy progressed as the modes of accountability were increased. However, the impact of the committees is hard to assess. Crispin Poyser, for instance, has pointed out the limited influence of the foreign affairs committee, partly because it has hardly any legislative power. ${ }^{24}$ Although the select committees have very limited legislative influence, Meghan Benton and Meg Russell, who have analysed their significance in detail, have come to the conclusion that approximately 40 per cent of committee recommendations are implemented or at least accepted by the government. ${ }^{25}$ The problem seems to be that the committees' activities are not necessarily reflected in what happens in the House itself: committee reports may remain undebated. On the other hand, some issues raised in the reports are addressed in parliamentary questions or adjournment debates. ${ }^{26}$ It can thus be concluded that the foreign affairs committee has strengthened the parliamentary scrutiny of British foreign policy, especially as it offers a regular and partially public forum for foreign policy debate.

A similar increase in parliamentary committees can be found in other representative democracies. A constant debate on the constitution, including the constitutional role of the parliament in foreign policy decision-making, is typical of any genuine parliamentary 
government. In the case of Denmark, for instance, the parliamentary foreign affairs committee (established in 1923) was originally seen as violating the rights of the government, but its position in foreign policy has strengthened. While the distinction between the intergovernmental and the supranational tends to become blurred in EU decision-making, the same is true of the roles of the government and the parliament in national foreign policy decision-making. ${ }^{27}$ René Lüddecke's comparative analysis suggests that the British, Danish and German parliaments have been eager to maintain their controlling powers over foreign policy, that the members of these parliaments have increased their foreign policy expertise and made effective use of the new possibilities to influence policy making created by the structural change in international relations resulting from globalisation, internationalisation and transnationalisation, and that since the end of the Cold War governments have tended to increasingly turn to their parliaments in times of crisis, all of which supports the thesis of an increased parliamentarisation and 'normalisation' of national foreign policy making. ${ }^{28}$ On the other hand, Dirk Peters and Wolfgang Wagner have argued that there has not been any discernible trend of parliamentarisation in decisions to deploy troops abroad, for instance. ${ }^{29}$

Rinna Kullaa and Teemu Häkkinen in their articles both note the role of the committees in the formulation of British foreign policy. In European Union matters, the house of commons foreign affairs committee and the house of lords European Union committee debated between 2008 and 2011 the formation of the EU's Common Foreign and Security Policy and the Common Security and Defence Policy, supporting these in principle but calling for parliamentary oversight of them. Teemu Häkkinen draws attention to the liaison committee, a cross-departmental committee founded in 2002 which addresses matters related to the work of committees generally and also conducts high-profile hearings, including those of prime ministers. The findings of Häkkinen on the liaison committee in connection with the war in Iraq point to its more formal role, which included hearing the evidence of Prime Minister Tony Blair on the constitutional arrangements and other political issues. 
As Teemu Häkkinen's present contribution and his doctoral dissertation ${ }^{30}$ demonstrate, attempts since the 1980s to redefine the status of Parliament vis-à-vis the royal prerogative in the British constitution have been evident in discussions on parliamentary involvement in debating and voting on military action (cf. Jonas Harvard on the Falklands War in this issue). In consequence, a cross-party consensus on the need for constitutional reconsiderations has emerged. Parliamentary activity would seem to have extended beyond the mere raising of public support through debate, the scrutinising of security policy through questions, keeping the ministers accountable and deciding on the provision of finances for the implementation of decisions on the use of force. The ongoing constitutional deliberation in the British parliament, which has connections at least with the US practice of voting on war in the Congress, is strongly tied to current contexts, and it is far from clear that the foreign policy role of parliament has been fundamentally rethought as a consequence of the Iraq War or the Syrian Civil War - despite the fact that these constituted turning points marking an increased intensity of foreign policy debate and consequent divisions. At the same time, select committees on public administration and on the constitution have more recently been in favour of further strengthening the parliamentary control of the exercise of the royal prerogative. This British development may have significance that goes beyond one nation state by providing a precedent for other parliamentary democracies to follow - as the British parliament has done so many times in the past. ${ }^{31}$

Like the other national parliaments of the European Union member states, the British constitution and parliament have been challenged by EU projects aiming to turn the European Parliament into a democratic representative institution of the whole Union and to create a common foreign and security policy. Rinna Kullaa shows that the reaction in the British parliament has continued to support representative government at the national level, emphasizing the sovereignty of the national parliament and the government's responsibility to it. The latter implies the need to keep parliament informed, to maintain national parliamentary 
scrutiny of foreign policy matters and to engage national parliaments in the oversight of EUlevel foreign and security policy decision making. In other words, the view has been that oversight by the European Parliament alone does not suffice.

\section{Links between Parliament and Civil Society}

In addition to the constitutional relations between parliament and the executive, the relation of parliament to civil society at large, especially nongovernmental organisations and the media, calls for attention. Members of parliament already had links with various extra-parliamentary associations in the 18th and 19th centuries. They were also obvious targets for lobbying by extra-parliamentary interests, or 'pressure groups', including those concerned with foreign

policy questions. ${ }^{32}$ Such connections were sometimes used further in exercising the constitutional rights of parliamentarians to supervise the government.

During the interwar era, there were complex connections between MPs and voluntary associations. For instance, a number of historians have noted the central role of the League of Nations Union (LNU), an organisation which promoted collective security and peace in international relations. However, the relationship between MPs and voluntary associations has previously been researched mainly from the perspective of the latter. Helen McCarthy has argued that the associations, which purposely had a non-party character, constituted a significant element in the British political culture of the era. ${ }^{33}$

It should be noted that the Union of Democratic Control (UDC) was influential in formulating Labour foreign policy in the years immediately following the First World War. Although its influence had waned by the early 1930s, it still had close contacts with MPs who tended to favour international co-operation through the League of Nations, disarmament, and, in the 1920s, the revision of the Treaty of Versailles. In her article, Satu Matikainen shows that the effect of extra-parliamentary pressure, mainly through voluntary associations, could 
be considerable, especially if it was combined with simultaneous pressure in parliament. The lines between extra-parliamentary and parliamentary action and between the activities of MPs and voluntary associations sometimes became blurred. The Union of Democratic Control, for instance, briefed MPs on tabling questions and formulating supplementary questions.

Parliamentary debates need to be contextualised with other forms of public discourse, since interaction between parliament and the press in the field of foreign policy was already considerable in the late 18th and 19th centuries. The press acted in two directions, informing the public about the debates of the parliamentary elite and communicating public opinion to the parliamentarians. Publicity became a factor for the legitimisation of parliamentary government, and parliament and the media became interconnected with regard to the subjects debated, the sites of their encounters and informal personal contacts. MPs with experience of the press learned to speak in ways that could have an impact in the media. By the 20th century, however, the electronic media had begun to take over the deliberative role of parliament. $^{34}$

Newspapers, pamphlets and other published writings on contemporary affairs allow us to see if certain issues were simultaneously raised in parliament and in public. Parliament could have a particularly important role in educating and leading public opinion rather than merely reflecting it - in informing the people about an international dispute or justifying engagement in a military conflict. Matti Roitto notes how exposure in the media together with simultaneous parliamentary pressure contributed to making the atomic energy issue subject to parliamentary scrutiny in 1945. As in the case analysed by Satu Matikainen, the coordination of parliamentary and extra-parliamentary activities could be regarded as constituting an actual campaign.

Jonas Harvard further explores how the relationship between media discourse and parliamentary discourse tends to be adjusted in times of crisis such as the Falklands War. His contribution reminds us of the different logics and dynamics of executive foreign policy 
decision-making, media debates dealing with an on-going story, and pro et contra argumentation in parliaments on a particular problem in a particular political context. In the circumstances of an involvement in an international conflict, parliament can assume the task of estimating the implications of certain kinds of foreign policy for public opinion both at home and internationally. Some members may appeal to world opinion in challenging the government's policy, while the media, for its part, gives expression to a supposedly united and patriotic national public opinion. This, despite solitary dissenting voices, unifies parliamentary and media discourses, at least in the initial phase of a conflict. While, in the circumstances of the early 1980 s, the government could still to some extent control the media - and indirectly domestic public opinion, parliament, and to a limited extent even opinions abroad - that has come increasingly difficult in the world of the 2010 s.

\section{A National Parliament and International Organisations}

Parliamentary involvement in foreign policy has also become more complicated since the First World War as a consequence of the emergence of an international level of (at least pseudo-parliamentary) debate. International organisations have affected the work of national parliaments since the founding of the League of Nations and the United Nations, creating possibilities for the members of national parliaments to discuss the national policy to be followed in the context of these organisations.

Satu Matikainen's and Matti Roitto's articles illustrate the ways in which international organisations were discussed in parliament and how the existence of such organisations correspondingly influenced the debates in a national parliament. Jonas Harvard shows how, in 1982, the resolutions of the UN Security Council constituted an important element in the parliamentary conception of 'world opinion', and Teemu Häkkinen draws attention to the discussion on the role of the Security Council vis-à-vis the British parliament in connection 
with the war in Iraq. These examples show that British parliamentarians were very interested in questions of legitimacy and the hierarchical relationships between decision making at the domestic and international levels.

The foreign policy role of parliaments has been further complicated by European integration - by the fact that the parliamentary oversight of foreign policy is no longer limited to the national level. Membership in the European Union has brought about a further change in the constitutional position of the national parliaments of the member states. ${ }^{35}$ An interesting question concerns the possibilities for a parliamentarised foreign policy at an international level, that is some sort of supra- or transnational foreign policy controlled either by a supranational or a joint body of national parliaments, or a combination of both. Any such development seems to seriously challenge the sovereignty of national parliaments, causing the members of these parliaments to rise in defence of their right to be involved in the decisionmaking process. As Rinna Kullaa suggests, a confrontation between the sovereign British national parliament and the European Parliament in the field of foreign policy has been more visible than in the case of most other national parliaments. The gradually strengthening role of the European Parliament as a foreign-policy-making body has changed the ways in which the relationship between parliaments and foreign policy is understood. The general reaction in Britain and elsewhere has been in favour of an increase in the control of foreign and economic policies primarily by national parliaments and secondarily by the supranational European Parliament. Representation at the EU level is not seen as offering an adequate substitute for representation through a national parliament, particularly in a field like foreign policy, in which the confidence of the representative bodies has tended to increase. As in many continental countries, the debate on parliamentary oversight at the EU level has contributed in Britain to an increased obscurity of the constitutional roles of the executive and parliament, with parliamentary committees getting more actively involved in such debates than used to be the case. 


\section{Conclusion and Ways Forward}

While the case studies in this special issue, often connected to particular crises, all support our initial hypothesis that the foreign policy role of the British parliament has tended to increase in the course of the 20 th and early 21 st centuries, this does not mean that foreign policy has become parliamentarised once and for all. The development should rather be seen as a further aspect of a very gradual and far from linear democratisation and parliamentarisation of policies in representative democracies - as part of a continuous discursive process of parliamentarism. Major international crises such as the two World Wars, the Falklands War and the Iraq War and post-war situations have provided moments for the reconsideration of the degree of the parliamentary oversight of foreign policy and led to minor reforms increasing the amount of information provided by the government to MPs. Parliament has not simply been a forum for rallying support and providing legitimacy for government policies; members on both sides of the government-opposition divide have often been keen to engage in debate on alternatives. MPs have been creative in their use of the available procedural means to force the government to allow them to debate certain aspects of foreign policy. Furthermore, they have made use of the multi-sitedness of policy debates and involved themselves in extra-parliamentary foreign policy discussions both in the media and in voluntary associations. While globalisation and integration have provided further possibilities to discuss foreign policy at the national level and even to conduct foreign policy at the supraand transnational levels, it has in the British case led to increasingly determined calls to reinforce the sovereignty of the national parliament in foreign policy issues.

Future research on the role of parliament in foreign policy might benefit from the extension of inter- and transnational comparative analyses between different national forums. According to Pasi Ihalainen and Kari Palonen, ${ }^{36}$ parliamentary debates constitute unique 
sources for the comparative study of political cultures from a conceptual history perspective, and this comparability also pertains to most of the other sources used here. National parliaments can be studied as a common European political institution controlling governments and the administration, the sovereignty of which has become increasingly challenged at the national level by media debates and at the international level by supra- and transnational politics. ${ }^{37}$ Another possibility for future research consists in an extended analysis of parliamentary discourse on foreign policy as part of a multi-sited (sometimes transnational) policy discourse. ${ }^{38}$ Such research strategies could further strengthen the comparative and multi-sited (transnational) aspects of foreign policy research.

\section{Acknowledgements}

The papers included in this special issue were originally presented in a workshop 'Parliamentary Means of Conflict Resolution in a Comparative Perspective', organised by the Academy of Finland Project 'Parliamentary Means of Conflict Resolution in TwentiethCentury Britain' (2010-13; decision number 131634) in cooperation with the School of History of the Freiburg Institute for Advanced Studies (FRIAS) on 16-17 March 2012. We wish to thank Stuart Ball, Armin Burkhardt, Norbert Götz, Peter Itzen, Jörn Leonhard, James Thompson and Uwe Wagschal, among others, for their helpful and constructively critical comments on the papers presented during the workshop. Preceding and later drafts have been discussed in the meetings of the project and seminars in General History held at the Department of History and Ethnology of the University of Jyväskylä, Finland, and have been commented on there by Anssi Halmesvirta, Markku Hokkanen, Miina Kaarkoski, Laura-Mari Manninen, Simo Mikkonen and Timo Särkkä, among others. Ville Häkkinen has helped with the technical editing. Gerard McAlester agreed to copy-edit the language of our contributions despite many other commitments, and Jari Ojala, as the Head of Department, subsidised this 
part of the project. Special thanks are also due to Clyve Jones for initially accepting our idea of a special issue of Parliamentary History and for guiding us through the process. We hope that this issue will open up visions for further exploring the complicated thematics of the parliamentary oversight of international relations.

${ }^{1}$ Kari Palonen, Jose Maria Rosales and T. Turkka, 'Introduction', in The Politics of Dissensus: Parliament in Debate, ed. Kari Palonen, Jose Maria Rosales and T. Turkka (Santander, 2014), 4-5.

${ }^{2}$ Peter G. Richards, Parliament and Foreign Affairs (1967), 13, 164.

${ }^{3}$ Cathal J. Nolan, 'The Influence of Parliament on Human Rights in Canadian Foreign Policy', Human Rights Quarterly, vii, 3 (Aug. 1985), 373-90; Ann Capling and Kim Richard Nossal, 'Parliament and the Democratization of Foreign Policy: The Case of Australia's Joint Standing Committee on Treaties', Canadian Journal of Political Science / Revue canadienne de science politique, xxxvi, 4 (Sep. 2003), 835-55.

${ }^{4}$ Lisa L. Martin, Democratic Commitments: Legislatures \& International Cooperation (2000); Davor Jancic, National Parliaments and European Constitutionalism: Accountability Beyond Borders, University of Utrecht PhD, 2011, http://igiturarchive.library.uu.n1/dissertations/2011-1004-200607/Jancic.pdf. ${ }^{5}$ Practices of Inter-Parliamentary Coordination in International Politics: The European Union and Beyond, ed. Ben Crum and John Erik Fossum (Colchester, 2013).

${ }^{6}$ Phoebe Chow, 'Parliament and the Problem of China, 1925-7: Priorities, Preoccupations and Stereotypes', Parliamentary History, xxix, 3 (2010), 360.

${ }^{7}$ Pasi Ihalainen, Agents of the People: Democracy and Popular Sovereignty in British and Swedish Parliamentary and Public Debates, 1734-1800 (Leiden and Boston, 2010); Kari Palonen, The Politics of Limited Times: The Rhetoric of Temporal Judgment in Parliamentary 
Democracies (Baden-Baden, 2008); European Parliaments under Scrutiny: Discourse Strategies and Interaction Practices, ed. Cornelia Ilie (Amsterdam, 2010).

${ }^{8}$ Jeremy Black, Parliament and Foreign Policy in the Eighteenth Century (Cambridge, 2004), 1, 6-7; Ihalainen, Agents, ch. 5; Pasi Ihalainen, 'Parlamentsdebatten und der Aufstieg ausserparlamentarischer Medien im späten 18. Jahrhundert. Schweden, Grossbritannien und die Niederlande', in Parlamentarische Kulturen vom Mittelalter bis in die Moderne. RedenRäume-Bilder, ed. Jörg Feuchter and Johannes Helmrath (Düsseldorf, 2013).

${ }^{9}$ A.J.P. Taylor, The Trouble Makers: Dissent over Foreign Policy 1792-1939 (1957), 65-6.

${ }^{10}$ Richards, Parliament, 22-3.

${ }^{11}$ Michael Foley, The Silence of Constitutions (1989); Philip Norton, 'Introduction: A Century of Change', Parliamentary History, xxx, 1 (2011), 2.

${ }^{12}$ Paul Seaward and Pasi Ihalainen, 'Key Concepts for the British Parliament (1640-1800)', in Parliament and Parliamentarism: A Comparative History of Disputes about a European Concept, ed. Pasi Ihalainen, Cornelia Ilie and Kari Palonen (Oxford and New York, 2016); Kari Palonen, 'Thinking of Politics in a Parliamentary Manner: Perspectives on the Conceptual History of Parliamentarism', in Parliament and Parliamentarism.

${ }^{13}$ Richards, Parliament, 23.

${ }^{14}$ Anssi Halmesvirta, 'The Casement Report, Foreign Policy and Public Moralism in the House of Commons', Aatehistorian harjoitus (Jyväskylä, 2012).

${ }^{15}$ Andreas Wirsching, 'Verfassung und Verfassungskultur im Europa der Zwischenkriegszeit', in Demokratie in der Krise. Europa in der Zwischenkriegzeit, ed. Christoph Gusy (Baden-Baden, 2008), 376.

${ }^{16}$ Detlef Lehnert, 'Verfassungsdispositionen für die Politische Kultur der Weimarer Republik - Die Beiträge von Hugo Preuß im historisch-konzeptiven Vergleich', in Pluralismus als Verfassungs- und Gesellschaftsmodel. Zur Politischen Kultur in der Weimarer Republik, ed. 
Detlef Lehnert (Opladen, 1993), 45; Norbert Götz, 'On the Origins of "Parliamentary

Diplomacy": Scandinavian "Bloc Politics" and Delegation Policy in the League of Nations', Cooperation and Conflict, xv, 3 (2005), 267, 273.

${ }^{17}$ Sally Harris, Out of Control: British Foreign Policy and the Union of Democratic Control, 1914-1918 (Hull, 1996).

${ }^{18}$ Harris, Out of Control, 241-2

${ }^{19}$ HC Deb 7 May 1940 vol. 360 cc1073-196; HC Deb 08 May 1940 vol. 360 cc1251-366.

${ }^{20}$ Nick Smart, 'Four Days in May: The Norway Debate and the Downfall of Neville Chamberlain', Parliamentary History, xvii, 2 (1998), 215-43.

${ }^{21}$ Parliament and International Relations, ed. Charles Carstairs and Richard Ware (Milton Keynes, 1991), 3.

${ }^{22}$ See also Matti Roitto, Divided Views: The Executive, Parliament and the Problematic Anglo-American Atomic Collaboration in the Changes of British Atomic Foreign Policy 1945-6, University of Jyväskylä PhD (2015).

${ }^{23}$ TNA, CAB 126/238, Rickett to Pimlott, late Oct. 1945.

${ }^{24}$ Crispin Poyser, 'Proceedings on the Record: the Floor of the House, the Foreign Affairs Committee and other Committees'. In Parliament and International Relations, ed. Charles Carstairs and Richard Ware (Milton Keynes, 1991), 28-32.

${ }^{25}$ Meghan Benton and Meg Russell, Selective Influence: The Policy Impact of House of Commons Select Committees (2011), 7-9.

${ }^{26}$ Benton and Russell, Selective, 95-96.

${ }^{27}$ Helle Krunke, 'Development in National Parliaments' Involvement in Ordinary Foreign Policy and European Policy - Denmark', European Public Law, xii, 2 (2007), 335-48; a similar influence of the EU on national foreign policy decision-making has been demonstrated by Tapio Raunio and Matti Wiberg, 'Parliamentarizing Foreign Policy Decision-Making: 
Finland in the European Union', Cooperation and Conflict, xxxvi, 1 (2001): 61-86, esp. p.

64.

${ }^{28}$ René Lüddecke, Parlamentarisierung der nationalen Aussenpolitik (Baden-Baden, 2010), $309-10,325-6,328$

${ }^{29}$ Dirk Peters and Wolfgang Wagner: 'Between Military Efficiency and Democratic Legitimacy', Parliamentary Affairs, lxiv, 1 (2011), 175-192.

${ }^{30}$ Teemu Häkkinen, The Royal Prerogative Redefined: Parliamentary Debate on the Role of the British Parliament in Large-scale Military Deployments, 1982-2003, University of Jyväskylä PhD, 2014, https://jyx.jyu.fi/dspace/bitstream/handle/123456789/42860/978-95139-5592-2_vaitos01022014.pdf?sequence=1.

${ }^{31}$ Pasi Ihalainen, 'European Parliamentary Experiences from a Conceptual Historical Perspective', in Parliament and Parliamentarism.

${ }^{32}$ See, for example, Richards, Parliament, 128-33.

${ }^{33}$ Helen McCarthy, 'Parties, Voluntary Associations, and Democratic Politics in Interwar Britain', The Historical Journal, 1, 4 (2007), 891-2; see also Daniel Gorman, 'Liberal Internationalism, the League of Nations Union, and the Mandates System', Canadian Journal of History, xl (2005), 449-55.

${ }^{34}$ Black, Parliament, 11, 13; Frank Bösch, 'Parlamente und Medien. Deutschland und Grossbritannien seit dem späten 19. Jahrhundert', in Das Parlament als Kommunikationsraum, ed. Andreas Schulz and Andreas Wirsching (Düsseldorf, 2012); Ihalainen, 'Parlamentsdebatten'.

${ }^{35}$ Norton, 'Introduction', 10.

${ }^{36}$ Pasi Ihalainen and Kari Palonen, 'Parliamentary sources in the comparative study of conceptual history: methodological aspects and illustrations of a research proposal', Parliaments, Estates \& Representation, xxix (2009), 17-34. 
${ }^{37}$ See for example Parliament and Parliamentarism.

${ }^{38}$ Language Policies in Finland and Sweden: Interdisciplinary and Multi-sited Comparisons, ed. Mia Halonen, Pasi Ihalainen and Taina Saarinen (Bristol, 2015). 